\title{
Richard Cobden in Prague - in 1838 Extracts from his Travel Diary ${ }^{1}$ (for František Stellner)
}

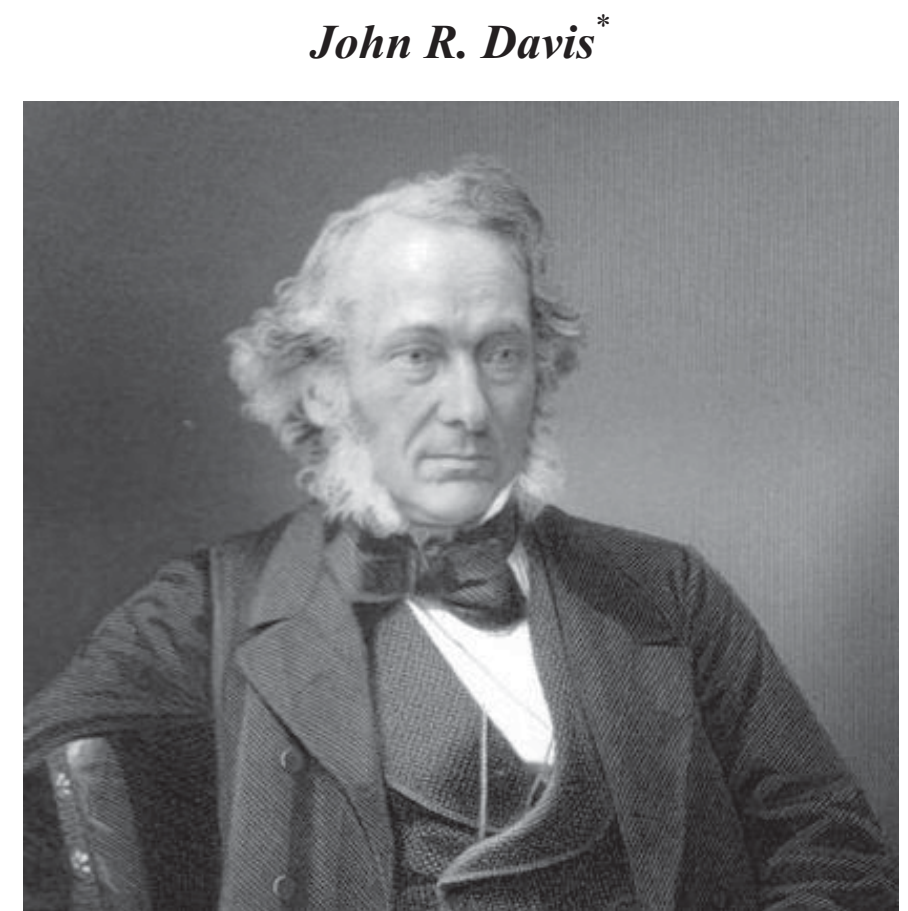

\section{Dresden - Saturday - Sepr. $15^{\text {th }}$}

Leave Hotel de Saxe at 5.a.m. - took up my travelling companion, a young Italian going to Prague to study German, in the suburbs - road flat to Pilnitz ${ }^{2}$, there go, whilst the horses are baiting, to walk through the gardens and to look in at the palace windows; the grounds are enclosed by the four sides of this palace, partly built in the grecian? ${ }^{3}$, and partly in the Chinese style, and yet notwithstanding this jumble of tastes the effect is not bad for the country - The enclosed gardens laid-out in parterres, are open to the public at all times, and I was told by my valet-de-place that company are allowed to fill the galleries of the saloon and look down upon the Royal party whilst dining - The road soon after leaving Pillnitz ascends for several miles, all at once the Bastei ${ }^{5}$ which had been concealed behind

* Prof. Dr. John R. Davis; Faculty of Arts and Social Sciences, Kingston University (j.davis@kingston.ac.uk).

1 Contained in Cobden Papers 451, W.S.R.O. Now published as John R. Davis (ed.), Richard Cobden's German Diaries, Saur, Munich, 2007.

2 Pilnitz: here misspelt, meaning Schloss Pillnitz: residence of the Saxon royal family. The gardens contain English, Chinese, Japanese and Indian architectural pieces.

3 "grecian?" is a correction of "german" in the manuscript here.

4 Valet-de-place: guide.

5 The Bastei: one of the most dramatic parts of the Elbe, the Bastei is a sheer cliff, beneath which the river flows. 
a screen of first burst on the eye, standing on a ledge hanging over a precipice of 800 feet high you look down upon the Elbe winding at the foot of the rock, beyond an undulating valley stretches away interspersed with isolated mounds of rock or conical hills, altogether a wonderful panorama reminding me a little of the Hill of Kinnoul in Perthshire but much more startling and abrupt - Another rocky precipice was formerly the eyrie of a strong robber who hurled down rocks upon the defenceless boats that passed along below - Query In what respect does the case of Great Britain holding violent possession of Gibraltar differ in principle from that of the brigand who seized by force the Bastei? We go from the Bastei to Pirna and there join the mail coach to Teplitz ${ }^{6}$. At Peterswald on the frontiers we changed the Saxon for an Austrian vehicle and our passports and luggage were examined. Several miles further on came to a hill the descent from which towards Teplitz afforded a glorious view - Pass the spot marked by three cast iron monuments to commemorate the spot where the battle of Culm ${ }^{7}$ was fought and Vendamme was made prisoner, an event that formed the turn of the tide in Bonaparte's long flow of good fortune - Reach Teplitz at 8, stop at the Post House - At supper am told by a German who came fellow passenger with us that he was engineer to the Petersburgh railroad which is six yards wide in the rails and has answered well - Whilst Mr. Brunel ${ }^{8}$ to whom he told all his experience upon this point would have 7" feet, and thus produced a failure -

\section{Sunday morning 16 Sepr. - Teplitz}

At 7 o'clock go in a carriage to visit the Millschauer Berg ${ }^{9}$ a conical mountain about three hours distant. The young Italian and I (by the way my companion and I cannot speak together, he not knowing French or English, and yet we are good friends) rode to the foot of the hill and then had a toilsome walk of 1" hours. The summit however was at last reached and it repaid us by its magnificent views of the surrounding country, the extent of which may be judged by the fact that the person keeping the restaurateur's at the top during the summer asserts that he has counted 500 villages and 24 cities from the top during a long summer day and that just before sun-set the cathedral of Prague may be seen with a good glass - This view is interesting to the Geologist from the great number of conical-shaped hills, the ruins on which will no less attract the notice of the antiquary, whilst the Soldier will have under his eye the whole theatre of the operations connected with the momentous battle of Culm. - It is in fact a sight treasured in my memory alongside the remembrance of the Falls of Niagara, the view from Catshill mountains - The passage of the Bosphorus \&c - Whilst at the top refreshing ourselves with bread, cheese, and tongue two Bohemian girls played airs on the harp and sang in accompaniment. Moss house in which are raised couches of this material for those who wish to pass the night here for the purpose of seeing the sun-rise - On our way pass the mouth of several coal-pits - The coal is however almost like wood, burns to a fine white ash, would not produce gas or serve for Engines - Price for a one horse car-load 1/6 at the door - On return I walk through the pleasure grounds, and

\footnotetext{
Teplitz: today Teplice in the Czech Republic.

Culm: Chlumec in Bohemia.

8 Isambard Kingdom Brunel. This refers to Brunel's disastrous attempt to introduce Broad Gauge railways on the London to Bristol line in 1838. In 1845 a Royal Commission found that the Broad Gauge was unsuitable, and unworkable in view of the wide use of the Standard Gauge. The Great Western Railway, however, only did away with Brunel's gauge in 1892.

9 Milleschauer Berg: Donnersberg bei Milleschau, near Teplitz, today known as Milešovka in the Czech Republic.
} 
pleasure gardens, belonging to the Hotels and bathing-places, see the Prince Clary ${ }^{10}$ playing with his sister in one of them, then took a bath where the King of Prussia, and Emperor of Russia bathe, charge including servant towels \&c 15d. After dinner look at the rifle shooting, the firing takes place from a small closet out of an open window at a target from two to three hundred paces off. Unlike the Swiss they hold their gun upon the rest whilst they press against by learning with all their weight against a catch in the muzzle, this is child's play - Then proceed to Prince Clary's country Palace to see the wild-boars and elk-deer, but find the former disposed of - The palace slovenly kept, and here as at Pilnitz and all other places there is little neatness or consistency like that perfect order and cleanliness found in an English nobleman's seat - Leave Teplitz at 8 in the evening by the mail for Prague - The young Italian, the dashing young Cockney shopkeeper from Vienna.

\section{Monday 17. Sepr. Prague}

Arriving at midnight at the ferry across the Moldau, hear the boatmen conversing in the Bohemian tongue, which is universally spoken by the working classes - It struck me to be softer than the German - Approach Prague in a thick fog which prevented my getting a view of the town. As we entered the streets was struck with the business-like air and apparent size and wealth of the place. Two mountaineers with olive complexions, sloe like eyes and lank straight black hair reminded me of our gipsies - After breakfast sally out with letters - Call on Mr. Semel a rich jew Banker ${ }^{11}$, thence to Mr. Meisner ${ }^{12}$ who has been in England, who takes me to view his cotton mill, the only one near the town, old and apparently not well kept. Mr. M. complains of losses and talks of stopping his machinery, says the spinners generally are doing no good - Girls earn from 2/- to 3/- a day; work from 5 in the morning till 8.p.m. with the interval of an hour for dinner, in winter 6 to 8. Says the spinners in Bohemia are in advance of those of Saxony, but no self-acting mules are in use A few power looms but they do not answer, labor being so cheap, the printers doing better than manufactures or spinners - Rape-seed oil mill belonging to the same person, he tells

10 The following extract may be relevant here from 8. 8. 1835, The Penny Magazine:

\section{ADMISSION OF THE PUBLIC TO PRIVATE GARDENS, \&c}

The following observations are extracted from a sensible little work lately published, called 'Dates and Distances.' They relate to one of the most important subject-important to the high and the low. The facts which the writer states are valuable for this reason: he shows that in Germany no cause of discontent exists between the upper and the lower classes; that mutual concessions produce mutual good will and mutual content and happiness. We do not agree with the writer in supposing that a similar state may not be attained in this country; and he who points out the means by which such an end may be gained will do good service to the community.

According to the kind and laudable practice observed almost universally by the German nobility, which I have before noticed, Prince Clary, who is the great proprietor of the vicinity (Teplitz), allows everybody access to his beautiful garden, which immediately adjoins the town. This privilege seems never to be exceeded, nor does it appear that any precautions are taken against its abuse. One ranges through the grounds without being spied at by gardeners or guardians; the indulgence is freely granted, and enjoyed with a freedom which is never disgraced by mischief. Prince Schwarzenberg permits all decently-dressed individuals to enter the gardens of his private residence at Vienna, and nobody thinks of plucking a single flower of the thousands which embellish the parterres. It would not be possible to establish this state of things in England: the rich would never tolerate such in intrusion on their privacy, and the public would soon arrogate to itself rights inconsistent with the rules of sufferance. People in Germany, however, are content to enjoy an indulgence as a concession, and deem it no humiliation to be obliged to their superiors. Indeed, there, obligations are conferred so much as a matter of course, that they are hardly perceived to be such. It is their habits, combined with the more even dissemination of riches, which create so much harmony among all ranks of society on the Continent, especially in Germany, and render the inferior classes so attached to those above them. The few who have immense wealth contrive to conciliate the great body of the people, by making them partakers of their luxuries, by opening to them their parks, gardens, and palaces, and by giving public fetes and entertainments.

11 Mr. Semel a rich jew Banker: unidentified.

12 Mr. Meisner: Note that Meisner is also mentioned in Cobden's letters to William Neild. 
me that the price of the seed in the last 10 or 12 years has advanced 50 pr.ct. Then go over a beet-root sugar refinery - The protective duty on colonial raw sugar is about $8 \mathrm{~s} /-$ a cwt Thinks the beet-root will eventually be cultivated without protection - Spoke of our own corn-laws - Nothing but a change in them could affect our trade with Bohemia - The late commercial treaty ${ }^{13}$ he characterised as being a farce only calculated to put the custom-house officers and merchants to a little trouble, it could have no effect upon our trade and was intended to have none - Says the minister of Commerce at Vienna sent questions to the Chambers throughout the empire desiring to know what articles ought to be stipulated to be admitted to England, and the answer from Bohemia was - "Agricultural produce - corn"- Says Bohemia in a good harvest produces food enough for three years consumption, and has no other natural surplus whatever to give in exchange for our manufactures. Spoke with ridicule and contempt of our policy - See a machine-making establishment kept by a Mr. Thomas an Englishman, spinning frames, steam Engines, tools, and all kinds of machinery The coals cost about 15/- to 16/- a ton laid down, but Thomas thinks although they are the best in Bohemia they are only two thirds the strength of the British and would not do for gas - he says that of the best Newcastle coals it requires $13 \mathrm{lbs}$ to the horse power an hour whilst of this it takes 20lbs - He spoke of a large establishment belonging to an English firm at Magdeburg - Then go to see a printing establishment belonging to Mr. Jerusalem ${ }^{14}$ (the jews have a monopoly of the Calico printing in the vicinity of Prague) employs about 80 block printers, the establishment is well kept, but French in the style of building, fulling machine a novelty, brushing do, and the girl to give the cross-movement to the doctor - Mr. Jerusalem although a jew a very liberal fellow and shall be treated as such if he comes to England. After dinner go, accompanied by Mr. Meisner in a carriage to the top of the hill which overlooks the City from the Calvary ground ${ }^{15}-$ A splendid view of old Prague, with its great variety \& number of towers and cupolas, and small minarets, its noble palaces, and hoary colleges all reminding one that it was once the favored seat of monarchy, and learning - the river Moldau sweeping round the greater part of the city, but cutting off one portion and giving occasion for a bridge of $1500 \mathrm{ft}$ flocked with passengers, the woody heights immediately at our feet - New paintings of the sufferings of Christ are erected on the Calvary gardens where we stood, and in which religious processions are sometimes performed, here saw a number of devout ladies kneeling before the pictures and at prayer-Mr. Meisner tells me that the government is now encouraging three mummeries more than under the former king, to keep the people back, but he says manufactures will stop it - On descending again to the town by another route pass several large palaces, some deserted, and others converted into hospitals \&c - Still the town is very much increasing in population, and houses are being erected in many quarters - Mr. M. says there are 120,000 people, they are proverbially well-dressed cleanly folks, see fewer soldiers than in Prussia, but am told the troops are manoeuvring at Juny Bunslow ${ }^{16}$ - Go to see a bobbin-net manufacture going by hand, an Englishman erected it, and it is no said to answer - Afterwards to the theatre or Opera - $\underline{\text { Somnambula }}^{17}$, the house not full, the performance tolerable.

13 The late commercial treaty: a 'Treaty of Commerce and Navigation between Her Majesty and the Emperor of Austria' was signed Vienna in July 1838.

14 Mr. Jerusalem: unidentified.

15 The Calvary ground: the Petrin Park and hill overlooking the old city of Prague.

16 Juny Brunslow: place unidentified, probably misheard or a poor transcription.

17 Somnambula: La Somnambula by Vicenzo Bellini (1801-1835). 


\section{Prague - 18 Sepr. Tuesday}

In the morning call upon Mr. Eidam ${ }^{18}$ who accompanied me to a glass warehouse, kept by Wincenz Nelstein ${ }^{19}$ where I made purchases - He told me the quality of the white or unstained kind, called crystal in Bohemia is now equal to English, - much cheaper, shewed me several purchases for England and America - but the sound is it appears not so good as the English - Afterwards call again upon Semel the Banker and thence proceed to the model infant school ${ }^{20}$ which I found to be superior in arrangement to any I had ever seen before - the master shewed us through - It has 240 children and there are five such in Prague, four for Christians, and one for jews - The furniture and ornaments of the school were of this character, bunches of ripe corn in ears, such as wheat, barley, oats, \&c - beside these hung a miniature flail - About 20 little vials hung against a board which was moveable, containing corn of every sort, peas, beans etc, as well as flour, bran, oatmeal \&c - Under these were hung the measures of the country in little tin cans - On one side stood a pair of scales, and near to these I observed little models of agricultural implements of all kinds, such as harrow, plough, waggon, horse in harness \&c - Then there was a complete model of a corn-mill, \& in a glass case amongst other little models or toys were those of a weaver and spinner at work - Against a board similar to that holding the bottles of grain were attached little models of all kinds of tools used by carpenters, builders, \&c - Another board has specimens of the different minerals in a raw state, and under them specimens of the same when made into simple articles of use, such as horse-shoes, brass-buttons \&c Upon another board (over which was the painting of a sheep) were little specimens of wool, wool attached to the leather, woollen yarn, and patterns of woollen and worsted goods in all kinds of colors and qualities, sheep's leather dressed \&c - On a board over which was the picture of a cow, were attached bits of leather of all kinds and in the different processes of tanning, and dyed of various colors. On another were specimens of printed cotton, woollen, silk, \&c - Another contained specimens of more woollens silks \&c - Another had the varieties of woods cut to shew the difference in the grain and labelled - A board containing specimens of the various furs of animals - Another containing all kinds of manufactures, such as linen, silk, woollen, and cotton in little patterns. Then there were small musical instruments, such as drums \&c for the children - a violin was lying on the table beside the master - Geological specimens, conchological - Do. Entomological Do. - stuffed birds Do. - There was a little model of an Apothecary shop - Drawings of horses-scripture pieces $\& c$ - The inner door was hung with drapery in good taste, with gilded wood work and surmounted by a picture of the Emperor - (The only thing to displease and which the master himself confessed he did not approve, was a collection of little wooden imitations of guns which the children were accustomed to use in their martial exercises) -

Children are taken at 2, learn Bohemian until 6 - and then go to a German school, begins at 9 , dine at 12 -again at 1 , and close at 6 - There is a play-ground behind the school of perhaps l' an acre, divided into two parts, the inner one contains a sort of dell closely planted with trees into which the children go to work or play in the cool shade during the heat of summer, in this garden are all kinds of flowers, fruits \&c - In the front is the school garden, where all kinds of grain \& vegetables are sown by the master in the presence of the children and the whole is afterwards explained as it grows, and when ripe gathered by the

18 Mr. Eidam: unidentified.

19 Nelstein: unidentified.

20 The model infant school: see Introduction on Cobden's involvement with educational reform and pedagogical theory. See also below for 25. September. See also Farrar, p.111, who also notes the significance of Cobden's commentary on the Prague and Vienna schools. 
little ones for use - N.B. This is a model-school to which even the jews sent their masters for examination, there is not I believe such another institution in the world!

After dinner (where beer is almost exclusively drunk) go with Mr. A. Meisner first to see an island fitted up with Cafés assemblies \&c, and the large space filled with trees furnished with tables, chairs, \&c for dinner or coffee parties - See also another similar establishment nearly finished - Then go to the rampart over the top of the Horse market to look down upon the town once more - Then to call at a bobbin-net manufactory where the machines are worked by hand, this also was established by an Englishman. Pay bill and enter the mail coach at " past 4 for Vienna which carried me to my destination in 37 hours. At the outskirts we take up Baron Charles Puteani ${ }^{21}$ and his son a boy going to Vienna to College. Scene with the sisters, and the servants, all kissing him in succession - he gives them bons-bons - Find my two companions very agreeable and polite - The Baron is proof that the march of intellect has reached even Bohemia; he tells me that he has made a fortune by buying, improving, and selling land \& mines, his father left him only Ł600, he can now afford to spend nearly twice as much a year - Gives me an invitation to visit him - Speaks about having a small steam-engine for his mines - Tells me he thinks the people in Bohemia are as well off as any-where, the Lombards the richest, Hungary very rich soil, but the people poor; Corn \&c sells in Hungary for little more than half the price in Bohemia for want of a vent - Says last year they did not know what to do with their grain in Austria it was so abundant - Arrive in the Austrian metropolis in the midst of a drizzling fog on the morning of $20^{\text {th }}$. Sepr. at 6 o'clock.

\title{
Richard Cobden in Prague - in 1838 Extracts from his Travel Diary
}

\section{John R. Davis}

\begin{abstract}
Richard Cobden belonged to a circle of the British intellectuals who admired German culture and philosophy. His interest grew further during his journey to the German states in the 1830s and 1840s. During his first journey in 1838 he visited for a short time the territory of Czech lands. To this short stay in Teplice and Prague the author dedicated this contribution in which he issues unpublished records from Cobden's diary. These reports contain a series of important findings and depict the everyday of the Czech lands in the end of the 19th century.
\end{abstract}

Key words: Germany; free trade; Bohemia; Great Britain.

21 Baron Charles Puteani: probably Karl, Count von Putteani, owner of Castle Triebsch (Třebušín) in Bohemia. 


\title{
Richard Cobden v Praze - v roce 1838 Výtah z jeho cestovního deníku
}

\begin{abstract}
Abstrakt
Richard Cobden náležel k okruhu britských intelektuálů, kteří obdivovali německou kulturu a filozofii. Jeho zájem ještě vzrostl při jeho cestách po Německu ve třicátých a čtyřicátých letech 19. století. Př́i své první cestě, v roce 1938, krátce zavítal také na území Čech. Právě této krátké zastávce v Teplicích a v Praze věnoval autor svůj ediční příspěvek, ve kterém zveřejnil dosud nepublikované záznamy z Cobdenova deníku. Tyto zprávy obsahují řadu důležitých poznatků, které dokreslují každodennost českých zemí na konci trricátých let 19 . století.
\end{abstract}

Klíčová slova: Německo; svobodný obchod; Čechy; Velká Británie 